УДК 378:373.31

DOI:

Тетяна Ситнік, доктор педагогічних наук, викладач кафедри початкової освіти Черкаського національного університету імені Б. Хмельницького

\title{
ФОРМУВАННЯ ДОСЛІДНИЦЬКИХ УМІНЬ В УЧНІВ 3 КЛАСУ НА УРОКАХ $З$ ІНТЕГРАТИВНОГО КУРСУ “Я ДОСЛІДЖУЮ СВІТ”
}

Статтю присвячено одній з проблем розвитку Нової української иколи, зокрема виробленню дослідниџьких умінь третьокласників на заняттях з навчального предмету “Я досліджую світ". У статті з'ясовано причину запровадження компетентністного підходу до навчання, в якому чільне місие посідає дослідницька компетентність, що складається з умінь аналізувати, порівнювати, зіставляти, узагальнювати природні і фізичні явища, події, процеси, виділяти в них головне й другорядне, проводити експериментальні diï.

Ключові слова: дослідницькі вміння; інтегративний курс "Я досліджую світ”; компетентнісний підхід; Нова українська школа; інновачійні методи навчання.

Jim. 11.

Tetyana Sytnik, Doctor of Sciences (Pedagogy), Lecturer of the Primary Education Department, Cherkasy Bohdan Khmelnytskiy National University

\section{FORMATION OF RESEARCH SKILLS IN STUDENTS OF THE 3RD GRADE IN LESSONS ON THE INTEGRATIVE COURSE "I EXPLORE THE WORLD"}

The article is dedicated to one of the important problems of the New Ukrainian School development, in particular, the development of research skills of young schoolchildren of the third grade in classes on the educational subject "I explore the world". The introduction of this course is due to the reform of secondary comprehensive school, which originates from the junior classes. The article found out the reason for the introduction of a competent approach to teaching, based on the development of the personality's abilities and development of basic, generally relevant and subjective competences in it. Among the basic competencies a prominent place is occupied by research, which is a set of skills to analyze, compare, summarize natural and physical phenomena, events, processes, and allocate the main and secondary in them, to carry out experimental actions. It is justified that it is the integrative course "I explore the world" that allows the teacher successfully produce research skills in students on the material of texts and tasks of the textbook, workbooks, and special multimedia programs. On the example of the topic "Traveling and discovering the world" specific features of the methodology for building fragments of the lesson which are aimed at solving educational problems, related to the formation of research skills of third-graders, are revealed. A set of tasks with texts, experimentation and solving various educational and cognitive situations is offered. Particular attention is paid to the use of modern innovative methods, techniques and teaching aids, in particular the use of a multimedia board.

Since the concept of "New Ukrainian School" offers primary school teachers to actively use the game as a method of learning, the article focuses on the method of introduction of various didactic non-simulation and simulation games in conjunction with interactive methods. The integrative course "I explore the world" allows you to effectively use the basics of knowledge of the history of Ukraine, geography, natural history, mathematics, chemistry, basics of health, literary reading, etc.

Keywords: research skills; the integrative course "I explore the world"; competent approach; New Ukrainian school; innovative teaching methods.

П остановка проблеми. За часи незалежності Української держави перед середньою загальноосвітньою школою виникало багато викликів, що змушували пошук нових підходів до освітнього процесу й формування нової особистості її випускника. Входження української вітчизняної освіти в загальноєвропейський освітній простір спонукало здійснення кардинальних змін у системі загальної середньої освіти, починаючи з початкової школи. Концепція “Нова українська школа”, що реалізується на сучасному етапі розвитку освіти, спрямована на формування нової гармонійно розвиненої особистості молодшого школяра. Її основні ідеї пов'язані 3 впровадженням компетентнісного підходу до навчання. Цей підхід грунтується на формуванні в учнів базових (ключових), загальнопредментних та предметних компетентностей.

Аналіз останніх публікацій. Запровадження компетентнісного підходу широко розглядається в працях сучасних педагогів, методистів, учителів. Як основу реформування середньої загальноосвітньої школи проаналізовано компетентнісний підхід у 
роботі О. Часнікова [11]; основні підходи до використання компетентнісного підходу у підготовці майбутніх учителів початкової школи грунтовно розкрито в монографії Л. Бірюк [1]; формуванню компетентностей у молодших школярів на урока у початковій школі розкрито в публікації О. Ліби та О. Хоми [10]; розвитку професійної компетентності майбутніх учителів початкової школи шляхом використання дидактичних ігор висвітлено у праці О. Жигайло [4]; сутність і структуру дослідницьких компетентностей майбутнього вчителя початкових класів обгрунтована у статті T. Ваколя [2]. Як важливу умову впровадження нових педагогічних технологій формування дослідницьких умінь учителя початкових класів розкрито в монографії О. Біди, Г. Волошиної, Г. Кловак [6].

Однак у науковій літературі недостатньою мірою відображено методичні підходи до формування дослідницьких умінь молодших школярів. Це й спонукало нас до написання статті.

Метою статті $\epsilon$ розкриття специфічних особливостей методики формування дослідницьких умінь третьокласників на уроках з інтегративного курсу “Я досліджую світ” у контексті вимог Нової української школи.

Виклад основного матеріалу. Компетентнісний підхід до навчання останнім часом став провідним в освітньому процесі як середньої загальноосвітньої, так і вищої школи. Його запровадження зумовлене прагненням вітчизняної освіти дорівнятися до загальноєвропейських стандартів. Компетентнісний підхід грунтується на виробленні в учнів комплексу необхідних для подальшої життєвої, освітньої, а в майбутньому професійної діяльності випускників школи. Як зазначено в Законі України “Про освіту”, “компетентність - динамічна комбінація знань, умінь, навичок, способів мислення, поглядів, цінностей, інших особистих якостей, що визначає здатність особи успішно соціалізуватися, провадити професійну та/або подальшу навчальну діяльність" [5].

Серед базових компетентностей чільне місце посідає дослідницька, яка становить собою “здатність особистості застосовувати в дослідницькій діяльності сукупність особистісних новоутворень, що відображають розвиток усіх сфер свідомості як умови становлення культури особистості" [8].

Формуванню дослідницької компетентності учнів початкової школи максимально сприяє предмет “Я досліджую світ”, який є за своєю суттю інтегрованою дисципліною, що поєднує у собі основи знань з історії України, географії, природознавства, астрономії, археології, математики, фізики, хімії, основ здоров'я, літературного читання тощо. Цей предмет вивчається протягом усіх років навчання в початковій школі. Основними темами, що розглядаються в цьому предметі, є: "Подорожуємо і відкриваємо світ", "Між минулим і майбутнім”, “Чарівні перетворення”, “Енергія”, “Світ невідомий”, “Світ невидимий”, “Приховані можливості речей”, "Погода", “Я - людина" тощо.

Уміщений у підручниках матеріал спонукає учнів, мандруючи рідним краєм, ознайомлюючись з кліматом, рослинним і тваринним світом рідної батьківщини, до проведення досліджень. Так, наприклад, підручник “Я досліджую світ" для третього класу вміщує алгоритм проведення будьякого дослідження: постановка проблеми; висування гіпотез; вибір способу дослідження; проведення дослідження; узагальнення результатів; оформлення матеріалів дослідження; презентація результатів [3, 40].

Для проведення дослідження за визначеними етапами вчитель спонукає учнів до використання різноманітних методів навчання: спостереження, порівняння, зіставлення, узагальнення i систематизація, експеримент.

Розглянемо методику роботи вчителя з учнями на прикладі засвоєння теми "Подорожуємо і відкриваємо світ”. Спочатку вчитель повинен ознайомити учнів із загальними відомостями про Україну, їі розташуванням, провідними містами, основними водоймами, природним багатством тощо. 3 цією метою доречно буде підготувати із залученням мультимедійної дошки презентацію, долучаючи до неї географічну карту України, основні символи Української держави (герб, прапор, гімн), текстовий матеріал, фотомалюнки iз зображенням краєвидів різних регіонів України.

Довідка для інформації. Україна - суверенна, незалежна, держава - розташована в центрі Свропи. Вона має багато сусідів. На півночі країна межує з Білоруссю, на півночі і сході - 3 Російською Федерацією, на заході - з Польщею і Словаччиною, на південному заході - 3 Угорщиною, Румунією і Молдовою. Довжина кордонів України становить 7590 км. Українські землі простяглися від Закарпаття до широких донських степів, від Полісся до берегів Чорного і Азовського морів. Дніпро, що протікає майже через усю територію країни, поділяє їі на дві частини - Лівобережну і Правобережну Україну. Столицею України є Київ (з енциклопедії).

Після розповіді вчителя, ознайомлення 3 текстом презентації учням пропонується 
доповнити інформацію про Україну назвами великих міст нашої держави і записати їх у зошит. А потім, після виконання цього завдання, на дошку вчитель проєктує перелік основних міст України. Учні порівнюють свої записи з правильною відповіддю. Якщо учні назвали всі міста, вони ставлять за виконане завдання собі десять балів, якщо ними пропущено одну назву -9 балів, якщо кілька -8 балів тощо.

Зразок запису на дошці. Серед найбільших міст України виділяють Київ, Харків, Дніпро, Донецьк, Одеса, Запоріжжя, Львів, Миколаїв, Чернігів і Луганськ.

Для кращого запам'ятовування найбільших міст нашої держави проводимо гру пропонуючи назвати ці міста в алфавітному порядку. Це дасть змогу учням засвоїти інформацію та повторити розташування літер за алфавітом, який вони вивчають на уроках української мови.

Доречним буде виконання практичного завдання встановити відповідність між відомими ознаками і фактами та назвами міст України, з’єднавши їх стрілочками.

Сучасна столиця України.

Перша столиця України.

Місто яке співзвучне за назвою річки.

Місто, засноване Данилом Галицьким.

Відоме місто шахтарів.

Місто, пов'язане із Запорізькою Січчю. відповіді на запитання, записані на інтерактивній дошці: чи вдалося вам відчути ефект подорожі під час прослуховування тексту? Що найбільше вам запам'яталося про видатні місця міста Лева? Чим відрізняється місто Львів від вашого рідного міста? Чи доводилося вам бувати у Львові? Які інші факти, крім поданих у аудіо записі, вам ще відомі про Львів? Усно перекажіть мандрівку “Я подорожую містом Лева”, додаючи інформацію про засоби пересування містом (автомобіль, тролейбус, автобус, маршрутне таксі, велосипед тощо).

Для того, щоб учням легше було зорієнтуватися, які види транспорту найчастіше використовуються під час подорожей, їм варто знати, що є транспорт міського та міжміського сполучення. 3 цією метою учитель вдається до використання одного $з$ інтерактивних методів навчання - роботи в творчих групах. Колектив класу об'єднується у дві команди, перша $з$ яких отримує завдання назвати види транспорту, за допомогою яких можна здійснити мандрівку від одного міста до іншого. Другій команді, пропонується пригадати, яким Дніпро транспортом можна здійснювати Запоріжжя подорож самим містом. Виграє та Київ команда, яка назве більшу кількість Донецьк видів транспорту.

Харків Також учням можна запропонувати Львів виконати завдання “Знайти зайве”. Це
Наступним кроком дослідження може стати заочна аудіомандрівка до міста Лева. Для цього завчасно готується магнітофонний запис тексту про Львів з використанням музичного супроводу.

$$
\text { Львів }
$$

Львів - красиве давнє місто, столиця Західної України. Майже 800 років тому його заснував князь Данило Галицький і назвав на честь свого сина Лева. Місто занесене до списку ЮНЕСКО. Найкрасивіший майдан міста - центральна площа Ринок. На схилах Замкової гори є парк “Високий замок”. Ця гора - найвища точка Львова. Якщо туди дістатися, можна помилуватися містом 3 висоти пташиного польоту. У Львові збереглися залишки кріпосних стін, ворота і вежа Арсеналу. Зараз тут розташований дуже цікавий музей зброї. Львів - найшоколадніше місто, тут навіть $\epsilon$ музеї шоколаду. Але найбільше вражають львівські кав’ярні й “цукерні” (Ю. Каспарова).

Після прослуховування тексту третьокласникам необхідно дати письмові
Завдання для другої команди Автобус

Потяг

Таксі

Літак

Маршрутне таксі

Персональне авто

Тролейбус

Мотоцикл

Трамвай

завдання навчить учнів розмежовувати види міського і міжміського транспорту. Перша команда працюватиме 3 назвами видів міського, а друга - навпаки.

Підручник для третього класу в межах цієї ж теми пропонує учням здійснити дослідження такого природнього явища, як павутиння. Цей приклад може послужити зразком для проведення іншого дослідження, пов'язаного із тривалим спостереженням за розвитком рослини кульбаби: від іiі цвітіння і до визрівання насіння. Учні протягом певного періоду спостерігають за перетворенням пелюстків жовтогарячої квітки на прозоро-білі кошики із суцвіття, які легким 
подихом вітру відриваються від основи i розлітаються на всі боки, щоб разом із насіннячком впасти в грунт. Учні за визначеними етапами дослідження описують цей процес і роблять свої висновки. Потім учитель пропонує молодшим школярам прочитати текст про цю рослину 3 енциклопедії та знайти в ньому інформацію, яка учнями під час дослідження не була врахована, а тоді вчитель ставить завдання за рахунок нової інформації розширити свої записи про спостереження. Подаємо текст, взятий 3 електронного джерела.

"Кульбаба - дивовижна квітка, яка схожа на сонечко і одним своїм виглядом піднімає настрій. Яскраве жовте забарвлення радує навесні, всіх хто його бачить. I назва у рослини дуже приваблива - кульбаба. Ця невибаглива рослина починає квітнути однією з перших, серед інших квітів. 3 приходом весни всі клумби, галявини, пустирі та газони покриваються жовтосонячними кольорами. Все навколо ніби покривається яскравим простирадлом. Ця трав'яниста багаторічна рослина досягає висоти 10-30 см. Квітки кульбаби складають суцвіттякошики. Такий жовтий кошик знаходиться високо на тоненькому стеблі. Листочки мають довгу загострену форму, з порізаними краями. У стеблі рослини знаходиться рідина, що нагадує молоко за кольором. Коли ж квітка відцвітає, то з'являється насіння. На кожній насінині зверху є білий пух. Через це, здається, ніби кульбаба одягла круглу пухнасту шапку. Повіє вітерець на кульбабку, яка відцвіла, і всі ці волоски розлітаються в сторони, розносячи насіння по полям, лугам, галявинам. 3 приходом весни 3 таких насінин виростуть нові квіти - кульбаби” [7].

Після проведеної такої роботи, учитель може запропонувати учням дати відповідь на низку запитань бесіди:

1. Як ви гадаєте, де ще може рости ця рослина, крім України?

2. Коли, у якому місяці відбувається дозрівання насіння кульбаби?

3. Як ви думаєте, для чого зверху насінини розташований білий пух, що має вигляд парашута?

4. Яку користь цвітіння кульбаб приносить бджолам?

5. Чи вам відомо, що цю рослину використовують в народній медицині в лікувальних цілях?

6. Чи доводилося вам смакувати варенням 3 кульбаб? Розкажіть про його макові якості.

7. Чи знаєте ви, що квіти кульбаб використовують дівчата для плетіння вінків? Кому доводилося 3 вас виготовляти такий віночок?
Розкажіть про техніку плетіння вінків 3 квіток кульбаб.

Цікавим для учнів, 3 метою перевірки засвоєння матеріалу про кульбабу на предмет виявлення їхньої спостережливості та уважності, буде завдання "Вилучити зайве в описі кульбаби": Рослина кульбаба складається 3 довгої тонкої ніжки, густої шапки з жовтогарячих дрібненьких пелюсток, широкого круглого листя, 3 ягідок, які утворюються після цвітіння.

Важливим для проведення дослідження $є$ безпосередня участь учнів у доборі матеріалу і здійснення експерименту. 3 такою метою пропонуємо третьокласникам спочатку у класі прочитати текст про комаху, відому у народі під назвою “сонечко”, а потім віднайти вдома на повір’ї цю комаху і дослідити іiі.

\section{Сонечка}

Сонечка, або Кокцінелімди, - відносно невелика родина ряду твердокрилих, яка налічує 5200 видів. Сонечка належать до комах із повним перетворенням (метаморфоз) і у життєвому циклі проходять стадії яйця, личинки, лялечки та імаго. Переважна більшість сонечок - хижаки.

Сонечка живуть у всьому світі, однак найчастіше зустрічаються в помірному поясі - у Європі й Північній Америці. Відносно рідко їі можна зустріти в тропічних лісах, де живе безліч інших видів жуків. Найчастіше сонечка живуть у середовищі, зміненому людиною: у садах, у лісових господарствах або на занедбаних, зарослих бур'янами територіях. На цих територіях у величезній кількості водиться попелиця, що є основною їжею сонечок. Крім попелиці, сонечка харчуються іншими комахами: червцями, білокрилками (алейродидами), павутинними кліщиками та ін. [9].

Під час спостереження учням необхідно звернути увагу на кольорове зображення поверхні комахи, на кількість чорних цяточок на ньому, наявність вусиків, кількість лапок, форму крил та їх зміни при злеті та описати результати свого спостереження. Завершальний етап спостереження - намалювати цю комаху.

Висновки і перспективи подальших розвідок. Отже, на уроках з інтегрованого курсу “Я досліджую світ" в учнів формуються дослідницькі вміння спостерігати, аналізувати, порівнювати, виділяти головне і другорядне, знаходити зайве, узагальнювати й систематизувати, здійснювати експеримент. Цьому сприяє використання активних методів навчання та використання сучасних технічних засобів, як наприклад, аудіо і відео техніки, комп’ютерів, мультимедійної дошки. Подальшого 
розвитку потребує такий аспект дослідження, як поєднання методик використання традиційних та інноваційних методів навчання на уроках 3 інтегрованого курсу “Я досліджую світ”.

\section{ЛIТЕРАТУРА}

1. Бірюк Л. Я. Комплексний підхід до фахової підготовки сучасного вчителя початкових класів: монографія. Глухів : РВВ ГНПУ ім. О. Довженка, 2012. $312 \mathrm{c}$.

2. Ваколя Т.I. Сутність і структура дослідницьких компетентностей майбутнього вчителя початкових класів. URL: https://scienceandeducation.pdpu.edu.ua/ doc/2011/7_2011/4.pdf

3. Волощенко О., Козак О., Остапенко Г. Я досліджуюю світ. Частина 1. Львів: ТОВ Видавництво "Світич". 2020. 74 с.

4. Жигайло О. Формування професійної компетентності майбутніх учителів початкової школи шляхом використання дидактичних та ділових ігор. Молодь і ринок. №11 (178). 2019. С. 133-138.

5. Закон України “Про освіту”. URL : https:// zakon.rada.gov.ua/laws/show/2145-19\#Text

6. Кловак Г.Т. Формування дослідницьких умінь учителя початкових класів - важлива умова до впровадження нових педагогічних технологій. Підготовка вчителя до впровадження нових технологій навчання в сільській початковій школі: монографія. Київ: Науковий світ, 2002. С. 55-69.

7. Кульбаба: опис для дітей. URL : https:// dovidka.biz.ua/kulbaba-opys-dlia-ditei/

8. Мерзликін О. До визначення поняття “дослідницькі компетентності старшокласників 3 фізики”. URL : https://core.ac.uk/download/pdf/ 228639866.pdf

9. Сонечко. URL : http://www.zoolog.com.ua/ besxrebet41.html

10. Хома О., Ліба О. Формування компетентностей у молодших школярів в контексті сучасних освітніх реформ. Освітологічний дискурс. 2018. № 1-2 (20-21). C. 291-302.

11. Частнікова О.В. Компетентнісний підхід в освіті як основа їі реформування. Народна освіта: електронне наукове фахове видання. URL : https:// www.narodnaosvita.kiev.ua/?page_id=2607

\section{REFERENCES}

1. Biryuk, L. Ya. (2012). Kompleksnyi pidkhid do fakhovoi pidhotovky suchasnoho vchytelia pochatkovykh klasiv: monohrafiia [A comprehensive approach to the professional training of modern primary school teachers: a monograph]. Glukhiv, 312 p. [in Ukrainian].

2. Vakolia, T. I. Sutnist i struktura doslidnytskykh kompetentnostei maibutnoho vchytelia pochatkovykh klasiv [The essence and structure of research competencies of the future primary school teacher]. Available at: https://scienceandeducation.pdpu.edu.ua/ doc/2011/7_2011/4.pdf[in Ukrainian].

3. Voloshchenko, O., Kozak, O. \& Ostapenko, G. (2020). Ya doslidzhuiuiu svit [I explore the world]. Part 1. Lviv, 74 p. [in Ukrainian].

4. Zhygailo, O. (2019). Formuvannia profesiinoi kompetentnosti maibutnikh uchyteliv pochatkovoi shkoly shliakhom vykorystannia dydaktychnykh ta dilovykh ihor [Formation of professional competence of future primary school teachers through the use of didactic and business games]. Youth and the market. No.11 (178). pp. 133-138. [in Ukrainian].

5. Zakon Ukrainy "Pro osvitu" [Law of Ukraine "On Education"]. Available at: https://zakon.rada.gov.ua/laws/ show/2145-19\#Text [in Ukrainian].

6. Klovak, G.T. (2002). Formuvannia doslidnytskykh umin uchytelia pochatkovykh klasiv - vazhlyva umova do vprovadzhennia novykh pedahohichnykh tekhnolohii [The formation of research skills of primary school teachers is an important condition for the introduction of new pedagogical technologies]. Teacher preparation for the introduction of new learning technologies in rural primary schools: a monograph. Kyiv. pp. 55-69. [in Ukrainian].

7. Kulbaba: opys dlia ditei [Dandelion: a description for children]. Available at: https://dovidka.biz.ua/kulbabaopys-dlia-ditei/ [in Ukrainian].

8. Merzlykin, O. Do vyznachennia poniattia "doslidnytski kompetentnosti starshoklasnykiv z fizyky" [To the definition of "research competencies of high school students in physics"]. Available at: https://core.ac.uk/ download/pdf/228639866.pdf[in Ukrainian].

9. Sonechko [Ladybug]. Available at: http:// www.zoolog.com.ua/besxrebet41.html [in Ukrainian].

10. Khoma, O. \& Liba, O. (2018). Formuvannia kompetentnostei u molodshykh shkoliariv v konteksti suchasnykh osvitnikh reform [Formation of competencies in junior schoolchildren in the context of modern educational reforms]. Educational discourse. No. 1-2 (2021). pp. 291-302. [in Ukrainian].

11. Chastnikova, O.V. Kompetentnisnyi pidkhid v osviti yak osnova yii reformuvannia [Competence approach in education as a basis for its reform]. Public education: electronic scientific professional publication. Available at: https:// www.narodnaosvita.kiev.ua/?page_id=2607[in Ukrainian].

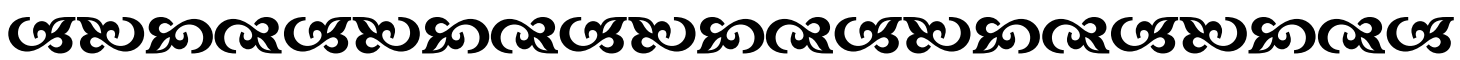

"Школа повинна дати те, чого треба життю".

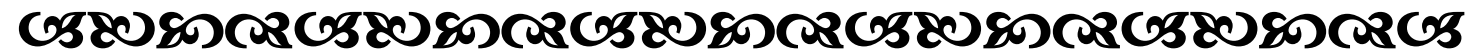

